\title{
The Bangsamoro Peace Process and Peacebuilding in Mindanao: Implications to Philippine Studies and National Development
}

\author{
Juvanni A. Caballero \\ Mindanao State University - Iligan Institute of Technology, Philippines \\ Mark Anthony J. Torres \\ Mindanao State University - Iligan Institute of Technology, Philippines
}

\section{INTRODUCTION}

As early as 1931, Moro leaders who were in favor of Moro integration into the Philippine body politichad already expressed their concerns on the marginalization of Mindanao and its native inhabitants. Datu Ibra, then representative of Lanao to the Philippine Legislature once said in his privilege speech:

A nation is like a human body. To be healthy, all its parts must be healthy. A man cannot be said to be healthy because his arms are strong provided his feet are weak... A beautiful Manila does not constitute a beautiful Philippines, and so we ask you to pay more serious attention to the problems of the south, which in progress is far behind the north. ${ }^{1}$

The above speech of Datu Ibra gives us a lot of insights. First, it reminds us that the Philippines cannot be complete without Mindanao. Hence, if we talk about Philippine development, Mindanao cannot be detached from it. Second, the speech reminds us that the problem in Mindanao is a Philippine problem. Thus, people from other parts of the country should not say: "Mindanao is too far from us" or "The problem in Mindanao is not our problem". After all, the war efforts to contain "Moro rebellion" are financed by Filipino taxpayers; Soldiers recruited to fight the Moro "rebels" often come from other regions of the Philippines; and Internally Displaced Persons (IDPs) from Mindanao migrate to overcrowded cities in Luzon and Visayas. Third, with respect to Philippine studies, Datu Ibra's speech reminds

\footnotetext{
1 "DatuIbra Makes Plea for Mindanao in Maiden Speech" Herald, 4 August 1931. Box 2834, Hayden Papers Copy at MSRC, MSU, MarawiCity.
} 
us that it cannot be complete without including Mindanao. This is especially relevant today because of the many events, commotions and developments in the region that unfold as a result of Moro rebellion, the peace negotiations and the peace building efforts of grassroots communities and international entities.

\section{THE BANGSAMORO PEACE PROCESSES: IMPLICATIONS TO NATIONAL DEVELOPMENT}

Mindanao has had two major peace negotiations since 1976: the first was with the Moro National Liberation Front (GRP-MNLF Peace Process, 1976-1996) and the second was with the Moro Islamic Liberation Front (GPH-MILF, 1997-present). Both were no easy processes as they encounter a lot of challenges, which include among others: factionalism of the Moro fronts; stringent interpretation of the constitution by those who oppose the peace negotiation;irresponsible media reporting; unsynchronized stance of the three branches of Philippine government; and the limited time that is often disrupted by intermittent episodes of cease-fire violations committed by both sides and complicated by spoilers.

More than the above-mentioned difficulties, the two peace processes had to deal with the deep-rooted prejudice, distrust and resistance of "Christian" Filipino majority who often regard any peace process with the Moros aswrong, immoral and unwise. For instance, when the 1996 Final Peace Agreement between the Philippine government and the MNLF stipulated, among others, that some 7500 MNLF combatants would be integrated into the Armed Forces of the Philippines and the Philippine National Police, many "Christian" Filipinos feared that the integration of MNLF combatants will not only downgrade the standards of the two government agencies but also endanger them by giving the rebels access to more powerful weapons and highly classified trainings. Many thought that the rebels would simply desert with their newly acquired weapons and skills to better fightthe government. More recently, the chair of the GPH Peace Panel and the Presidential Adviser on the Peace Process were tagged by those who oppose the peace negotiationsas traitors because they see them as lawyering and defending the MILF after the Mamasapano incident. It must be mentioned that the misencounter in the small town of Mamasapano has nothing to do with the proposed Bangsamoro Basic Law but is now threatened to be scrapped because of the incident. ${ }^{2}$ Worse, not a few "Christian" Filipinos believe that the creation of a truly autonomous government for the

\footnotetext{
${ }^{2}$ The incident was actually a natural consequence of the uncoordinated unilateral move of the Special Action Force of the Philippine National Police, which refused to coordinate not only with the Philippine military and other relevant agencies of government but also refused to tap the well-tested security mechanism like the Ad-Hoc Joint Action Group (AHJAG), which was the body agreed by the GPH and MILF to arrest criminals in areas deemed to be under the influence of the MILF. To ensure coordination and avoid misencounter, this body is composed of selected MILF, AFP and PNP elements.
} 
Bangsamoro people would only lead to Muslims oppressing Christians; to more corruption and underdevelopment; to espousing more conflicts and wars; to grave abuse of power by Moro leaders; to dispossess Christians of their lands and expel them out of Mindanao.Blinded by their bias and poor grasp of the Bangsamoro question, many Filipinos fail to realize that ensuring the success of the peace process is everybody's responsibility because if it succeeds, the entire country will certainly benefit. Unfortunately, however, instead of helping the peace process, many seem to be apathetic if not working against it - making every stepdifficult and countering every little gain of the peace talks.If only everyone could cast their biases and helpthe peace process by accepting the compromises which the government and the Moro rebels toiled so hard for so many years just to come to common terms, then everyone will surely see the following:

1. The biggest armed group in the southern Philippines ending their rebellion. The MILF, which claimed to have more than 10,000 strongcombatants (the biggest armed group in the Philippines at the moment) has agreed to decommission its weapons and forces and live normal lives once all the agreement points are done. With this, the Armed Forces of the Philippines can be relieved of the burden of quelling Moro rebellion and can then redirect its focus and energy to their original mandate which is external defense - an area equally needing a lot of government attention especially with our territorial dispute with China in the West Philippine Sea. The redeployment of the military will also relieve them of the burden of running after the criminal elements within the Bangsamoro as it becomes the main task of the Bangsamoro government itself.

2. The territorial integrity of the Philippines is saved. The Moro rebels had originally demanded independence which could disintegrate the territory of the country. But the GPH panel has convinced them that independence is not necessary if they only want to exercise their right to self-determination. Now, they settle for autonomy so long as it is genuine. Also note that originally, they refused to be called Filipinos, but now accepted that they can be Filipinos by citizenship but Bangsamoro by identity. This is already a great step towards Filipino nation-building in the south!

3. Improved governance in the Bangsamoro. The government and the MILF have agreed that for governance to improve it has to be anchored on the principle of subsidiarity. This term meant that the locals know better the context and nature of their problems. As such, they are in a better position to identify the most viable approach to solving their problems. Taken into the context of the Bangsamoro, Muslim Mindanao cannot continue to be governed from the remote Manila. After all, the former know better the cultural, psychological, social and political context of their own communities than the latter. 
One might argue that the ARMM is autonomous already and that it is not governed from the remote Manila. Well, common knowledge would tell us that while the ARMM bears the word "Autonomous", it is not truly autonomous because it does not have fiscal autonomy as it continues to beg the national government for its annual budget; It does not have control over its natural resources as the national government continues to decide over the matter; It does not have full powers over its constituent local government units as they continue to be governed by the Local Government Code; It cannot even collect important taxes (e.g. capital gains tax, documentary stamp tax, donor's tax and estate tax) because it is the national Bureau of Internal Revenue that is collecting these. Logic would tell us that if the Bangsamoro is entrenched and it will be led by the MILF, the leadership would strive hard to make it succeed by improving its tax collection because the annual block grant will not forever be provided to them. As stipulated in the Comprehensive Agreement on the Bangsamoro, the block grant will be gradually decreased until it becomes zero at a certain period of time. After all,this is the meaning of autonomy - standing on your own feet and not depending on the national government forever. It is therefore important that the MILF should make tax collection efficient, otherwise, they will lose not only financial resources necessary to efficientlyrun the new autonomous government but more importantly the trust and confidence of their own people.

4. Fiscal independence of the autonomous region. The establishment of a truly autonomous region will relieve the national government of subsidizing the predominantly Muslim provincesof Mindanao as the future Bangsamoro will have to stand on its own feet financially. As mentioned already, the block grant will only be temporary and that for the autonomous government to become financially independent, it must create its own sources of revenue, attract foreign grants and donations, contract loans and credits and collect taxes which the national government finds it very difficult to collect at the moment. In this way, the burden of tax collection is shorn off from the shoulders of the national government while the new autonomous government is made to own the obligation.

5. Improved relationship between the national government and the Bangsamoro people.There is a Moro expression which says: Goberno a Sorrowing a Tao. Referring to the Philippine government, this expression literally means government of the foreigners. To the MILF and their communities, it is not just a foreign government but worse, it is one that is fond of sending them bullets, tanks, warplanes and bombs - a government that desires nothing but their demise and destruction. In the Comprehensive Agreement on the Bangsamoro, we see the government acting like a real 
parent to his child - trying to win the heart of his "rebellious" child; preparing and capacitating him to stand on his own feet; and letting go of him once he knows how to walk on his own. The Moros generally appreciate this act of the government.

6. More constructive use of government funds. Not known to those who advocate for war in Mindanao, the government spends a huge amount of money to finance the war. From 1970 to 1996, government expenditures for combat expenses alone amounted to Php73 billion. During the 2000 all-outwar, government expenditures reached Php6 billion. The same amount could have been used to construct a lot of classrooms, purchase plenty of medicines for government health centers and hospitals, install new infrastructures and introduce new livelihoods. If the peace process succeeds and the war is over, financial resources of the government can be devoted then to constructive endeavors rather thanfor destruction.

7. Tapping of the natural resources of Mindanao which could reverse the economic condition not only of the Bangsamoro but the country as a whole. It is not a secret that Mindanaois endowed with fertile lands that produce a variety of food and industrial crops. In fact, it is said to produce $40 \%$ of the country's food supply ${ }^{3}$ and is expected to fare well in other business opportunities such as seaweed farming, light manufacturing, furniture and wood products, telecommunications, and energy and water sources development.

Based on US intelligence assessment in $2006^{4}$, Mindanao possessesa huge reservoir of untapped resourcesbelieved to worth between US $\$ 840$ billion to US\$1 trillion. Minerals and fossil fuels are said to abound in the Liguasan marsh, other parts of the Cotabato Basin, Davao-Agusan Basin and the area straddling between Tawi-Tawi and Sulu. The latter are also said to be rich in natural gas and oil deposits ${ }^{5}$. In an earlier report in $1990^{6}$, Malaysia's national oil company Petronas identified sites in mainland Mindanao that are rich in natural gas and oil. This includes DatuPiang (Dulawan) and Sultan Sa Barongis in Maguindanao and Lambayong in Sultan Kudarat. The presence of these mineral and gas deposits could mean that the country's

${ }^{3}$ Don Agrasada, Peace Derivatives and probabilities in Muslim Mindanao (Part 1) An Analysis of the Arroyo Administration's Conflict Management in the Southern Philippines (online publication by the Association of Asian Research) accessed 2/10/2015.

${ }^{4}$ Angelo L. Gutierrez, "US says Mindanao has \$1-T untapped mineral resources", The Philippine Star, 24 August 2011. 7 February $2015<$ http://www.philstar.com/>

${ }^{5}$ Fernando Jose, "Mindanao Marshland yields one trillion dollars", 22 May 2012, Dead Man's Diary, 10 February 2015<http://fernanjoseangeles.blogspot.com/>

${ }^{6}$ Jose 2012 
growth may largely be dependent on Mindanao. Tapping these resources may be the key to reversing the economic situation of the entire Philippines.

8. Brighter prospects for Mindanao in the ASEAN economic community The geo-economic configuration of Mindanao ${ }^{7}$ also underscores its viability and importance as gateway to the ASEAN economic community (AEC) through the Brunei Darussalam-Indonesia-Malaysia-the Philippines- East ASEAN Growth Area (BIMP-EAGA) platform. Launched in 1994 in Davao City, the BIMP-EAGA has already provided the building blocks for Mindanao as the Philippines' gateway to the AEC - establishing cross border connectivity, socio-cultural exchange, and trade harmonization policies with neighboring countries. Owing to its geographic location, Mindanao is in the best position to take advantage of the opportunities offered by the ASEAN economic integration. Thus the success of the current peace process will definitely ensure brighter prospects for Mindanao in the single ASEAN economy.

Aside from the above, Mindanao and the Sulu Archipelago sit astride one of the most important sea lanes in Maritime South-East Asia which underscores its value in fostering stability in the region. Note that a turbulent southern Philippines affects not only our country but our neighbors' as well.

The discussions above clearly show that ensuring the success of the Bangsamoro peace process will not only benefit Mindanao but the entire country as well.

\section{THE BANGSAMORO PEACE PROCESS AND PEACEBUILDING IN MINDANAO: IMPLICATIONS TO PHILIPPINE STUDIES}

The current peace process put Mindanao into the center stage of action which should generate a lot of activities for the Philippine studies scholar. The Track I peace process between the GPH and MILF, for instance, bring to the fore a constellation of important issues and questions on the future of Mindanao. The Track II (horizontal) peace building efforts at the grassroots level also floats a lot of areas for documentation and inquiry. But who are looking into all of these? Who are tackling the above issues and questions? If there is a group that should deal with them, it should be the Philippine studies scholars!

Now, if we are to categorize the issues/questions generated by the peace and conflict situation in Mindanao, we see two (2) broad themes where scholars of Philippine studies can focus on: First, are enduring questions which are issues in the past that

\footnotetext{
${ }^{7}$ Don Agrasada, Peace Derivatives and probabilities in Muslim Mindanao (Part 1) An Analysis of the Arroyo Administration's Conflict Management in the Southern Philippines (online publication by the Association of Asian Research) accessed 2/10/2015.
} 
are still affecting the current peace process; and, second are emerging topics that have surfaced along with recent developments in the peace talks.

One example of an enduring issue is that of the Philippine claim over North Borneo (i.e., Sabah). This became very prominent in the news and tabloids in 2013 when alleged royal armed forces of the Sultanate of Sulu occupied one of the towns in the eastern part of $\mathrm{Sabah}^{8}$. The resurfacing of such issueis a clear attestation that this is still one topic that needs utmost contemplation by Philippine Studies scholars.How will Malaysia's role as third-party mediator affect the Philippine claim on Sabah? Should the Bangsamoro pursue its interest on Sabah? What is its implication to the regional cooperation amidst ASEAN economic integration? Are there options for a win-win solution over North Borneo/Sabah?

How about justice issues for individuals and families affected by the violent conflicts during the Ilaga-Baracudaclashes in the 60s and 70s, the Martial Law, the 2000 all-out-war and the 2008 debacle caused by the scrapping of the Memorandum of Agreement on Ancestral Domain (MOA-AD)?

And what about the seemingly constant factionalism among Moro revolutionary groups; the compartmentalized agencies within the government that appear to be detached (if not indifferent) to the peace negotiation; the Christian majority of the country whose bias against the Moro prevents them from seeing wisdom in the peace process? These are only few of the enduring questions that the Philippine studies scholar can delve into.

But of course, there is more to that! The Philippine Studies scholar may opt to tackle emerging issues generated by recent developments. For instance, he/she may investigate the effectiveness of the CSO's peace building initiatives; how coherent are they with the Track I peace process; and which areas need improvement in their efforts.

Scholars can also embark to answering questions pertaining to the implementation of the CAB. Such questions include who will ensure that all elements in the CAB will be fully implemented; how can we hurdle difficulties in bringing about normalization; what transitional justice and reconciliation measures will be done to effectively deal with the wounds of the past?

How about questions on the relationships between Moro and non-Moro peoples of Mindanao? Will the establishment of the Bangsamoro increase tension between the Moro inhabitants of the mainland and those of the Island provinces; What about the plight of the indigenous peoples living within the Bangsamoro territory? And how

\footnotetext{
${ }^{8}$ RoelPareño, "Sulu Sultan's army stakes Sabah claim," The Philippine Star 16 February 2013, 6 February $2015<$ http://www.philstar.com/>
} 
about the entire architecture of the peace process - what are its strengths and areas needing improvement? These are only some of the issues that scholars in Philippine studies can inquire into.

Looking at all the issues and questions above, it is clear that the two tracks of the peace process at present offer a lot of research opportunities for Philippine Studies scholars. But beyond research, however, the same peace process can also be viewed as avenues for scholars to conduct extension activities with research components.

The project of the Center for Philippine Studies of the University of Hawaii (UH) at Manoa and the Mindanao State University (MSU) is an example of the kind mentioned above. The project, which is funded by the United States Institute of Peace (USIP),aimed atingesting peace education into the History 3 curriculum (History of the Filipino Muslims and Indigenous Peoples of Mindanao Sulu and Palawan) of MSU. It must be mentioned that while MSU requires all of her students to take History 3 (for them to understand and appreciate the contribution of the Moro and Lumad to Philippine History), there was no standard content, approach and material in teaching the course. Hence, the learning of our students is made dependent on the political, ideological and even ethnic leanings of our teachers. USIP and the Center for Philippine Studies of UH came to the rescue by introducing to us a project that trains teachers in how to teach Mindanao History using a peace lens. More than being an extension activity, this project includes a research component thattreats the enriched History 3 curriculum as an intervention that affects the knowledge and attitudes of students towards other ethnic groups. This project certainly complements the Track I peace process because it optimizes the impact of a course that is taken by more or less 50,000 students of the MSU System. Can you imagine the impact of transforming 50,000 young Mindanawons every year into peace advocates who can stay resilient in the middle of conflit and living the values of pluralism, respect and understanding?

The example above is only one of the numerous research and extension opportunities that the current peace process offers. Of course there are countlessopenings where the Philippine studies scholar can explore to contribute not only in generating knowledge about Mindanao but also in solving "real-world" problems at "real-time" setting.I therefore invite fellow scholars of Philippine studies to delve into the constellation of important issues and topics that the peace process in Mindanao opened for us.

\section{PHILIPPINE STUDIES FOR WHAT?}

But before proceeding to study Mindanao, we must ponder: Why are we going to write and tell the stories of Mindanao? What is our motivation: Is it only to balance the seemingly Luzon-centered Philippine studies; Or to help address real problems? 
Personally, I would prefer the latter to be our motivation for studying and writing about Mindanao.

It is my appeal therefore to fellow scholars to help steer the boat of Philippine Studies towards the direction of peace-building by writing articles on Mindanao using a peace lens. By this term, I actually mean three things: 1.) If we write, we critically assess issues and develop understanding using multiple perspectives; 2.) If we stress, we stress points of convergence rather than divergence; 3.) If we look at a problem, we do not dwell on the problem, rather, we offer solutions to the problem. Mindanao has suffered already not only because of the bad publicity about it but more importantly by the lack of critical but constructive studies about the region and its people. This is the chance for Philippine Studies scholars to make a difference!

\section{References and notes :}

Agrasada, Don. (2015).Peace Derivatives and probabilities in Muslim Mindanao (Part 1) An Analysis of the Arroyo Administration's Conflict Management in the Southern Philippines". Association of Asian Research,10 February.

Concepcion, Sylvia et al.(2003). Breaking the links between economics and conflict in Mindanao. Manila: International Alert.

Dwyer, Leslie and RufaGuiam. (2012) Gender and Conflict in Mindanao. Manila: The Asia Foundation.

Human Development Network. (2005). Philippine Development Report . Manila: Human Development Network.

Schiavo-Campo, Salvatorreand Mary Judd. (2005).The Mindanao Conflict in the Philippines: Roots, Costs, and Potential Dividend. The World Bank.

Mindanao. (2015). Def. Encyclopedia Britannica Online.

Calica, Aurea and Jose RodelClapano.(2015) "Gov't, MILF, sign final annex." The Philippine Star 26 January 2014. 6 February.<http://www.philstar.com>.

Fernandez, Amanda T.(2015) Roadmap for Peace: Highlights of the Bangsamoro framework agreement.GMA News Online 15 October 2012. 6 February $2015<$ http://www.gmanetwork.com>

Gutierrez, Angelo L.(2015).US says Mindanao has \$1-T untapped mineral resources. The Philippine Star 24 August 2011. <http://www.philstar.com>.

Jose, Fernando Jose. (2015).Mindanao Marshland yields one trillion dollars". Dead Man's Diary 22 May 2012. < http://fernanjoseangeles.blogspot.com/>

Pareño, Roel.(2015) Sulu Sultan's army stakes Sabah claim”.The Philippine Star 16 February 2013. <http://www.philstar.com>.

Sabillo, AngeliSabillo.(2014). What is the Comprehensive Agreement on the Bangsamoro?. Inquirer.net. $<$ http://newsinfo.inquirer.net $>$. 


\title{
Summary
}

\section{The Bangsamoro Peace Process and Peacebuilding in Mindanao: Implications to Philippine Studies and National Development}

\author{
Juvanni A. Caballero \\ Mindanao State University - Iligan Institute of Technology, Philippines \\ Mark Anthony J. Torres \\ Mindanao State University - Iligan Institute of Technology, Philippines
}

This paper is all about how integral Mindanao is to the Philippines. As such, Mindanao studies should not only be at the periphery of Philippine studies. The recent developments in Mindanao should be enough reason for scholars to devote significant amount of their attention to the region. After all, the peace processes in Mindanao, both vertical and horizontal, have generated a constellation of issues and questions for them to delve and study. More critically, this paper interrogates the gaps in Mindanao and Philippine studies, arguing that scholars can contribute to the success of the peace processes not only by engaging in research but also by initiating extension activities with research components. Here, I will discuss, as an example, initiatives from the academe (e.g., the partnership on peacebuilding between the University of Hawaii and Mindanao State University, under the aegis of the United States Institute of Peace) that complements the vertical peace process.Finally, the paper is an invitation for scholars to help steer the boat of Philippine Studies towards the direction of peace-building by writing articles on Mindanao using a peace lens.

Key words: Mindanao, peace process, Philippine studies, peace-building, peace-lens 